\title{
Hematology, Other
}

National Cancer Institute

\section{Source}

National Cancer Institute. Hematology, Other. NCI Thesaurus. Code C20039.

The medical specialty that pertains to the anatomy, physiology, pathology,

symptomatology, and therapeutics related to the blood and blood-forming tissues. 